\title{
Pengaruh Nilai Carbon Equivalen (CE) Dari Cast Iron Pada Proses Penangkaian Anoda Di Rodding Plant
}

\author{
Effect Of Equivalent Carbon (Ce) Value From Cast Iron In Anode Circuit Process In \\ Rodding Plant
}

Dede Ibrahim Muthawali

Departemen Kimia Fakultas Matematika dan Ilmu Pengetahuan Alam

Universitas Sumatera Utara

Email: ibrahimdede87@yahoo.com

\begin{abstract}
ABSTRAK
Penambahan zat aditif akan mempengaruhi nilai Carbon Equivalent (CE) cast iron. Nilai Carbon Equivalent adalah parameter yang menyatakan berapa banyak carbon yang terkandung di dalam cast iron tersebut. Nilai Carbon Equivalent yang ditentukan antara 4,7-4,9. Apabila Carbon Equivalent (CE) pada cast iron tersebut kurang dari 4,7-4,9 maka cast iron tersebut akan mudah retak sehingga menyebabkan anoda panggang pada tangkai anoda akan lepas dan pemakaian cast iron tidak optimal, dan bila melebihi angka tersebut maka cast iron akan sulit dilepaskan dari tangkai anoda. Dari hasil pengamatan yang telah dilakukan diperoleh nilai Carbon Equivalent (CE) cast iron yaitu 3,76 dan 4,7 . Hal ini menunjukkan bahwa nilai Carbon Equivalent cast iron masih memenuhi syarat dan memenuhi standar yang telah ditetapkan yaitu antara 4,7-4,9.
\end{abstract}

Kata Kunci: Cast iron, Nilai Carbon Equivalent, Anoda panggang, Tangkai anoda, Zat aditif

\begin{abstract}
ABSTRAK
Addition of the substance will effect the value of carbon equivalent (CE) cast iron. Carbon equivalent value is a parameter that tells us how much carbon is cointained in the cast iron. Carbon equivalent values were determined between 4,7 to 4,9 . When the carbon equivalent (CE) on the cast iron is less than 4.7 to 4.9 then it will be easy to cast iron, causing cracks in the baked anode rod will come loose. And usage cast iron is not optimal. And when more than that value so cast iron will difficult loose from the anode rod. From the observations that have been made obtainable carbon equivalent (CE) cast iron are 3,76 and 4,7. This indicates that the value of carbon equivalent (CE) cast iron still eligible and meet the standars that have been established which is between 4,7 to 4,9 .
\end{abstract}

Keywords: Cast iron, Carbon equivalent value, The baked anode, Anode rod, The substance 


\section{A. PENDAHULUAN}

Dalam memproduksi logam-logam seperti natrium, kalsium, magnesium, emas, titanium dan aluminium, reaksi oksidasi dan reduksi selalu merupakan bagian dari industri-industri skala besar. Prosesnya terjadi spontan memerlukan energi dan berlangsung searah. Aluminium merupakan salah satu logam yang paling banyak dipakai di dalam kehidupan sehari-hari. Aluminium merupakan unsur nomor tiga terbanyak ditemukan di alam yaitu sekitar 7,28 persen pada kulit bumi.

Untuk mendapatkan aluminium yang memiliki kualitas, dan kemurnian yang tinggi sangat dipengaruhi oleh anoda yang digunakan dalam proses penangkaian anoda. Pada proses peleburan alumina menjadi aluminium membutuhkan anoda dan katoda dimana anoda merupakan elektroda dengan muatan listrik positif dalam proses elektrolisa (sebagai reduktor). Anoda yang digunakan berasal dari material karbon(C) yang terdiri dari kokas, butt, dan skrap mentah sebagai filter serta hard pitch sebagai pengikat sedangkan katoda adalah elektroda yang bermuatan listrik negative yang dalam proses elektrolisa merupakan elektroda tempat terjadinya reaksi reduksi sebagai oksidator (grojetheim, 1998).

Kokas merupakan bahan pengisi (filter) anoda berasal dari sisa-sisa destilasi minyak bumi. Kokas (coke) yang biasa digunakan adalah coke yang sudah dikalsinasi (calcined coke). Pabrik peleburan aluminium terdiri dari tiga bagian yaitu pabrik karbon, pabrik reduksi, dan pabrik penuangan. Pabrik karbon terdiri dari tiga proses yaitu pabrik pencetakan anoda mentah (green plant), pabrik pemanggangan anoda (baking plant), dan pabrik penangkaian anoda (rodding plant). Green plant adalah pabrik pembuatan anoda mentah (green anoda block) untuk kebutuhan proses elektrolisa di pot reduksi. Anoda mentah tersebut bahan bakunya antara lain kokas, coal tar pitch, butt dan skrap. Baking plant adalah tempat untuk pemanggangan green block (anoda mentah) yang berasal dari green plant. Tujuan pemanggangan untuk mengkalsinasi pitch yang ada dalam green block (GB) yang kemudian pitch tersebut akan berikatan dengan kokas dan butt. Rodding plant adalah pabrik penangkaian anoda, dimana anoda yang sudah selesai dipanggang akan dikirim ke rodding plant untuk ditangkai, dirakit menggunakan cast iron (besi tuang). Setelah selesai ditangkai anoda tersebut dinamakan Anoda Assmbly dan siap dikirim ke pabrik reduksi.

Terjadinya proses penangkaian anoda membutuhkan cast iron (besi tuang) untuk menyambungkan antara baked block (BB) dengan rod(tangkai anoda) pada proses casting. Cast iron (besi tuang) adalah besi yang mempunyai kandungan karbon antara 2,5\% sampai $4,0 \%$ yang mempunyai sifat kandungan lasnya (weldability) rendah. Karbon dalam cast iron (besi tuang) dapat berupa simentit $\left(\mathrm{Fe}_{3} \mathrm{C}\right)$ atau biasa disebut carbon bebas (grafit). Cast iron (besi tuang) mempunyai nilai Carbon Equivalent (CE) antara 4,7-4,9. Apabila Carbon Equivalent (CE) pada cast iron tersebut kurang dari 4,7-4,9 maka cast iron tersebut akan mudah retak dan terlepas dari rod(tangkai anoda) dan apabila nilai Carbon Equivalent(CE) pada cast iron lebih dari 4,7-4,9 maka cast iron (besi tuang) tersebut akan sukar untuk dilepas dari rod( tangkai anoda) karena nilai CE nya sudah mendekati baja (PT INALUM, 2003).

Jadi pabrik karbon memproduksi blok anoda, blok anoda ini sendiri berfungsi sebagai elektroda di pabrik reduksi yang memproduksi aluminium cair. Selanjutnya aluminium cair ini dicetak menggunakan Casting Machine dan menghasilkan bentuk batangan yang disebut ingot.

\section{Unsur Karbon}

Karbon mempunyai berat atom 12,011 dan nomor atom 6, terbagi atas 3 isotop: ${ }^{12} \mathrm{C},{ }^{13} \mathrm{C},{ }^{14} \mathrm{C}$. Bahan karbon banyak terdapat dalam senyawa organik yang umumnya mengandung hydrogen, nitrogen, dan sulfur. Struktur karbon terdiri dari: amorf, grafit dan intan. Bentuk amorf yang umum antara lain adalah arang, kokas bubuk karbon (karbon black). Dalam grafit pola atom tersusun berlapis, sehingga relative lebih mudah bergeser terhadap sesamanya (ikatan kovalen dengan tiga dimensi).

Bila senyawa organic mengalami reaksi (polimerisasi kondensasi) tanpa oksigen maka berat molekulnya akan meningkat dan akan berubah menjadi senyawa aromatik polysiklik. Pada temperatur $400-500^{\circ} \mathrm{C}$ senyawa ini disebut juga benda padat hitam 'black solid' atau 'carbon precursor' struktur dari karbon precursor tergantung pada bahan dasarnya dan kondisi perlakuan panas. Peristiwa terpenting selama perlakuan panas pada temperatur tinggi 
ini adalah pertumbuhan Kristal grafit. (Utomo, Tjipto, 1984).

\section{Unsur Aluminium}

Aluminium diambil dari mineral bauksit. Nama bauksit diambil dari nama daerah baux (Beaux) di Perancis dekat St.Renny. Bauksit sebenarnya bukan merupakan nama suatu mineral, tetapi merupakan campuran koloid oksida-oksida $\mathrm{Al}$ dan $\mathrm{Fe}$ yang mengandung air. Istilah bauksit dipergunakan untuk bijih yang mengandung aluminium monohidrat atau trihidrat berupa mineral-mineral gibsit.

Sifat-sifat aluminium antara lain, penghantar listrik yang baik, sangat ringan dan lunak dengan berat jenis 2,7 titik cair $657^{\circ} \mathrm{C}$ dan titik didih $1800^{\circ} \mathrm{C}$, mudah dikerjakan / dituang, penghantar panas yang baik, tahan karat, dan non magnetik, mudah ditarik dan ditempa dan digulung, menjadi keras setelah mengalami pekerjaan dingin dan menjadi lunak setelah dipijarkan serta mudah berkarat setelah terkena alkali lemah.

Bauksit terbentuk karena pelapukan mineral-mineral yang mengandung alumina. Endapan yang cukup besar terjadi di daerah yang beriklim tropis dan subtropics yang basah, banyak hujan suhu tetap sepanjang tahun dan penyaluran air dipermukaan tahan relative baik. Bauksit di pulau Bintan berasal dari pelapukan serpih pelitik yang sudah berubah menjadi hornfels apanitik karena metamorphose sentuh sebagai akibat intrusi granitic.

Karena bauksit umumnya terjadi pada permukaan atau dekat permukaan dan merupakan letakan-letakan mendatar, maka cara penyelidikan yang benar adalah melakukan pemetaan geologi yang ditinjak lanjuti pada pembuatan sumur (test pit), pada endapanendapan yang agak tebal dapat dilakukan pemboran dangkal.

Aluminium merupakan logam yang belakangan ini digunakan dalam jumlah besar di dalam industri logam modern. Aluminium banyak digunakan dengan pertimbangan sifatnya yang ringan penghantar panas dan listrik yang baik, tahan korosi dan tidak beracun, mudah dibentuk, bersifat non magnetik serta mempunyai daya tarik yang relatif dibanding beratnya. Oleh sebab itu aluminium digunakan sebagai atap bangunan, kerangka bangunan, kosen pintu dan jendela, kerangka partisi ruangan, kereta, alat-alat pengangkutan terutama industri pesawat terbang, industri rumah tangga seperti mesin cuci, air condition, industri kaleng dan alat-alat pembungkus, industri kimia logam.

Dalam pemakaian khusus terutama sebagai pengganti tembaga, yaitu dimanfaatkan untuk peralatan listrik, kabel listrik, untuk hantaran tenaga listrik, hantaran listrik tegangan tinggi di atas tanah(dililit dengan kawat baja), hantaran transmisi, macam-macam mesin kumparan, untuk pipa. Sebagian besar komponen pesawat terbang mempergunakan aluminium. Barang bekas yang terbuat dari aluminium dicairkan kembali, kemudian dicetak menjadi berbagai bentuk alat rumah tangga yang tidak berkarat dan ringan antara lain sendok dan garpu dan lain sebagainya (Sukandarrumidi, 2008).

Aluminium diperoleh dari jenis-jenis tanah liat tertentu (bauksit). Bauksit mula-mula dipisahkan terlebih dahulu tanah tawas murninya (oksida aluminium). Setelah itu pada oksida aluminium cair dikalsinasikan suatu prosedur elektrik. Oleh karena suhu lumer oksida aluminium sangat tinggi yaitu $2050^{\circ} \mathrm{C}$ maka pengolahan aluminium sangat sukar. Logam alumimium mempunyai rumus kimia $\mathrm{AL}$, mempunyai berat jenis 2,6-2,7 dengan titik cair $659^{\circ} \mathrm{C}$. Aluminium adalah logam lunak, dan lebih keras dari pada timah putih, tetapi lebih lunak dari pada seng. Warna dari aluminium adalah putih kebiru-biruan.

Aluminium dapat dihasilkan melalui proses elektrolisa. Proses elektrolisa yang dikembangkan untuk produksi industrial adalah proses elektrolisa Hall Heroult. Proses tersebut merupakan elektrolisis larutan alumina $\left(\mathrm{Al}_{2} \mathrm{O}_{3}\right)$ di dalam lelehan kriolit $\left(\mathrm{Na}_{3} \mathrm{AlF}_{6}\right)$ pada temperatur $960^{\circ} \mathrm{C}$ sehingga dihasilkan aluminium cair (PT INALUM, 1988).

\section{Mekanisme Proses Elektrolisa}

Elektrolisa adalah peristiwa kimia yang melibatkan dua atau lebih spesies kimia yang berbeda, yang terjadi pada kedua elektroda (anoda dan katoda), dan berlangsung apabila aliran listrik searah, DC (Direct Current), dialirkan ke dalam suatu pelarut elektrolit. Reaksi yang terjadi pada persamaan adalah reaksi sebagai berikut:

$2 \mathrm{Al}_{2} \mathrm{O}_{3(\mathrm{~s})}+3 \mathrm{C}_{(\mathrm{s})} \rightarrow 4 \mathrm{Al}_{(\mathrm{l})}+3 \mathrm{CO}_{2(\mathrm{~g})}$

Mekanisme yang terjadi dalam proses tersebut adalah alumina diumpankan ke dalam elektrolit dan terpisah ion aluminium yang bermuatan positif( $\left(\mathrm{Al}^{3+}\right)$ dan ion oksigen yang 
bermuatan negatif (02-). Arus searah dialirkan dalam tiap-tiap sel, sehingga menggerakkan ion-ion menuju arah yang berlawanan. Ion oksigen bergerak kea rah anoda, lalu bereaksi dengan karbon membentuk karbondioksida $\left(\mathrm{CO}_{2}\right)$, sedangkan ion aluminium bergerak kea rah katoda, lalu akan hilang muatannya membentuk aluminium (Al).

Bahan baku dalam proses Hall-Heroult terdiri dari alumina, elektrolit, katoda dan anoda. Proses Hall-Heroult memproduksi aluminium dengan mereduksi aluminium dari bahan baku alumina dalam proses elektrolisis yang digerakkan oleh arus searah yang mengalir dari anoda ke katoda dengan kriolit sebagai elektrolit (Donet, 1976).

\section{Pemakaian Aluminium}

Titik cair $660^{\circ} \mathrm{C}$ dan titik didihnya $1800^{\circ} \mathrm{C}$. Untuk bahan penghantar kemurniannya mencapai 99,5\% dan sisanya terdiri dari unsur besi, silicon dan tembaga. Aluminium murni sangat lemah dan lunak (tembaga lebih kuat disbanding aluminium), untuk menambah kekuatan biasanya digunakan dengan menggunakan logam campuran.

Aluminium lebih menguntungkan dibanding tembaga bila digunakan untuk hantaran yang tidak memerlukan penyekat (misalnya hantaran transmisi di atas tanah) sebab daya hantar panas/daya hantar listriknya kira-kira 60\% daya hantar listrik tembaga sehingga untuk mendapatkan tahanan yang sama dengan tembaga (yang panjang dan penampangnya sama) dibutuhkan penampang 60\% lebih besar namun demikian beratnya sama ringan dibanding tembaga.

Aluminium adalah logam sangat ringan (berat jenis aluminium 2,56 atau 1/3 berat jenis tembaga) dan tahanan jenis $2 \times 10^{-8}$ atau 1,25 kali tahanan jenis tembaga. Sifat tahan tarik aluminium dalam keadaan dingin 17$20 \mathrm{~kg} / \mathrm{mm}^{2}$. Oleh sebab itu aluminium hanya bisa dipakai untuk lebar tegangan yang pendek, untuk tegangan yang panjang dipakai kabel aluminium (beberapa kawat dipilih) dengan kawat baja sebagai intinya. Aluminium tidak baik untuk dipatri, tetapi dapat dilas, las dapat menyebabkan tegangan tariknya menjadi turun karena panas yang ditimbulkan. Oleh karena itu hantaran tegangangan aluminium dengan sambungan patri atau las harus diberikan jepitan.
Aluminium yang tipis sekarang dapat menggantikan kertas perak (yang dipakai antara lain pada kondensor). Aluminium juga bisa dipakai untuk chasis pesawat radio. Barang-barang aluminium dapat terlapis oleh oksida aluminium. Dalam udara terbuka dapat melindungi bagian bawah aluminium dari zat asam dan mencegah oksidasi lebih lanjut. Lapisan ini merupakan tahanan yang sangat tinggi (Sumanto, 1994).

\section{Pabrik Peleburan}

Aluminium terutama diproduksi untuk pembuatan alloy yang ringan. Di USA saja aluminium diproduksi lebih dari 1 juta ton per tahunnya. Pengolahan logam aluminium dibagi menjadi dua tahap, yaitu tahap pemurnian dan tahap elektrolisis. Pengolahan ini dinamakan proses Hall, sesuai dengan nama penemunya yaitu Charles martin Hall (1863-1914).

\section{Tahap Pemurnian}

Aluminium diproduksi dari bauksit yang mengandung pengotor $\mathrm{Fe}_{2} \mathrm{O}_{3}$. Pengotor ini harus dihilangkan dengan cara melarutkan bauksit tersebut dalam $\mathrm{NaOH}$ (aq). Besi oksida $\left(\mathrm{Fe}_{2} \mathrm{O}_{3}\right)$ yang bersifat basa tidak larut dalam larutan $\mathrm{NaOH}$. Pengotor dipisahkan dengan penyaringan. Selanjutnya, aluminium diendapkan dari filtrate dengan mengalirkan gas $\mathrm{CO}_{2}$ dan pengenceran. Dan didapatkan alumina murni.

\section{Tahap Elektrolisis}

Selanjutnya pada tahap kedua, reduksi $\mathrm{Al}_{2} \mathrm{O}_{3}$ dilakukan melalui elektrolisis menurut proses Hall Heroult. Metode elektrolisis itu ditemukan secara terpisah tetapi hamper bersamaan pada tahun 1886 oleh dua orang peneliti muda, yaitu Charles M. Hall di Amerika Serikat dan Paul Deroun di Perancis. Kita ingat bahwa $\mathrm{Al}_{2} \mathrm{O}_{3}$ mempunyai titik leleh yang sangat tinggi, yaitu lebih dari $2000^{\circ} \mathrm{C}$. Oleh karena itu elektrolisis lelehan $\mathrm{Al}_{2} \mathrm{O}_{3}$ murni tidak ekonomis. Dalam proses Hall-Heroul, $\mathrm{Al}_{2} \mathrm{O}_{3}$ dilarutkan dalam lelehan kriolit $\left(\mathrm{Na}_{3} \mathrm{AlF}_{6}\right)$ dalam bejana dari baja berlapis grafit yang sekaligus berfungsi sebagai katode. Dengan cara itu elektrolisis dapat dilangsungkan pada suhu $950^{\circ} \mathrm{C}$. Sebagai anoda digunakan batang grafit. Elektrolisis menghasilkan aluminium di katoda, sedangkan di anoda terbentuk gas oksigen dan karbon dioksida.

Selain Hall, ada juga proses Bayer, yang dikembangkan oleh Karl Josef Bayer, seorang ahli kimia berkebangsaan Jerman. Proses ini 
biasanya digunakan untuk memperoleh aluminium murni. Bauksit halus yang kering dimasukan ke dalam pencampur, diolah dengan soda api $(\mathrm{NaOH})$ di bawah pengaruh tekanan dan pada suhu di bawah titik didih. $\mathrm{NaOH}$ bereaksi dengan bauksit menghasilkan aluminat natrium yang larut.

Setelah proses selesai, tekanan dikurangi dan ampas yang terdiri dari oksidasi besi yang tak larut, silicon, titanium dan kotoran lainnya ditekan melalui saringan dan dikesampingkan. Cairan yang mengandung alumina dalam bentuk aluminat natrium dipompa ke dalam tangki pengendapan, kemudian dibubuhkan kristal hidroksida aluminium terpisah dari larutan. Hidroksida aluminium kemudian disaring dan dipanaskan sampai mencapai suhu $980^{\circ} \mathrm{C}$. Alumina siap dilebur.

Logam aluminium dihasilkan melalui proses elektrolisa dimana alumina berubah menjadi oksigen dan aluminium. Alumina murni dilarutkan ke dalam kriolit cair (natrium aluminium flourida) dalam dapur elektrolit. Arus listrik dialirkan dalam campuran melalui elektroda karbon. Pada saat tertentu, aluminium disadap dari sel dan logam cair tersebut dipindahkan ke dapur penampung untuk dimurnikan atau untuk keperluan paduan, setelah itu dituang ke dalam ingot.

Bahan baku bauksit, masih merupakan campuran aluminium oksida, besi (III) oksida dan silica. Jadi ada dua tahap dalam produksi aluminium yaitu reaksi pemurnian untuk memperoleh alumina murni dan tahap elektrolisis.

\section{Cast Iron}

Secara umum besi tuang (cast iron) adalah besi yang mempunyai Carbon Content 2,5\%$4 \%$. Oleh karena itu besi tuang yang kandungan karbonnya 2,5\%-4\% akan mempunyai sifat mampu lasnya rendah. Karbon dalam besi tuang dapat berupa simentit $\left(\mathrm{Fe}_{3} \mathrm{C}\right)$ atau biasa disebut dengan karbon bebas (grafit). Perlu diketahui juga kandungan fosfor dan sulfur dari material ini sangat tinggi dibandingkan baja. Besi tuang dapat mengandung unsur-unsur sebagai berikut:

Karbon: $3 \%-4 \%$

Silicon: $1 \%-3 \%$

Mangan: 0,5\%-1\%

Belerang: $<0,1 \%$

Phosphor: $<1 \%$

\section{Pengaruh Unsur-unsur Terhadap Sifat Besi Tuang}

Karbon yang berada dalam besi tuang berupa grafit atau besi karbid (sementit) yang rapuh. Bila besi tuang banyak mengandung sementit maka besi tuang menjadi rapuh dan sulit diolah. Berikut adalah unsur-unsur yang berpengaruh terhadap sifat besi tuang (cast iron).

a. Silikon (Si) sebagai penguat karbon dalam pembentukan struktur grafit dan fluiditas cast iron

b. Mangan $(\mathrm{Mn})$ sebagai pereaksi dengan sulfur sehingga membentuk mangan sulfida yang berfungsi sebagai 'desulfing agent'. Kelebihan sulfur dapat mengakibatkan temperatur didih meningkat, mengganggu fluiditas dan dapat mencegah pembentukan Kristal grafit.

c. Belerang (S) menstabilkan sementit sehingga menyebabkan besi menjadi rapuh.

d. Phosphor (P) menurunkan titik lebur cast iron dan membentuk fluiditas cast iron.

e. Carbon (C) untuk pembentukan struktur grafit dan $\mathrm{Fe}_{3} \mathrm{C}$ (sementit) sehingga cast iron jadi lebih keras. (Jan, P.L.1979).

Tujuan penelitian ini adalah untuk mengetahui berapa nilai Carbon Equivalent (CE) dari cast iron (besi tuang) yang dihasilkan, untuk mengetahui pengaruh cast iron yang dihasilkan terhadap proses penangkaian anoda dan untuk mengetahui faktor-faktor yang mempengaruhi nilai Carbon Equivalen (CE) dari cast iron(besi tuang) pada proses penangkaian anoda.

Manfaat penelitian ini adalah dapat mengetahui kualitas yang sesuai dengan standar terutama terhadap nilai Carbon Equivalen (CE), mengetahui faktor-faktor yang mempengaruhi nilai Carbon Equivalen (CE) dari cast iron(besi tuang) pada proses penangkaian anoda dan dapat mengetahui pengaruh cast iron(besi tuang) yang dihasilkan terhadap proses penangkaian anoda.

\section{B. METODOLOGI}

Bahan dan Alat

ATC (Anoda Transport Car), L0-401, P and F Conveyor, Crush Breaker (CB), Belt Convenyor, Crusher (CR), Gizzy Fidder (FG), Bucked Elevator (BE), Siever (SR), Silo (S), Press (PR), 
Magnet Sperator (MS), Shot Balst (SB), Inspector (IS), Induction Furnase (IF), Ladle, Catrige, Timbangan, Pengaduk, Strain Transport Car (STC), Conveyor Machine (CM), Drying (DR), Hummer Mill (HM), Magnet Sperator (MS).

Bahan yang digunakan pada penelitian ini adalah Recycle Cash Iron, Pig Iron, Ferro Silikon $(\mathrm{Si})$, Ferro Mangan (Mn), Ferro Posfor (P), Kokas.

\section{Pelaksanaan Penelitian}

\section{Prosedur Penerimaan Butt Assembly}

1. Rakitan Butt Assembly di transfortasikan dari gedung reduksi menuju penangkaian dengan menggunakan ATC (Anoda Transport Car).

2. Butt dari ATC (Anoda Transport Car) digantung pada $\mathrm{P}$ dan $\mathrm{F}$ Conveyor di stasiun LO-401

3. Rakitan Butt yang telah diterima dikirim dan diprosespada crush dan butt system.

\section{Prosedur Pemecahan Crush dan Butt System}

1. Crust dipisahkan dari butt assembly menggunakan CB-401.

2. Crust yang dipisahkan di CB-401 dihancurkan ke BC-402 yang selanjutnya masuk ke BC-403 hingga masuk ke CR-401 dan dihancurkan.

3. Crust kemudian diteruskan ke GF-401 untuk memisahkan aluminium metal

4. Return crust masuk ke BE-401 untuk dialiri ke SR-401

5. Di SR-401 crust diayak untuk mendapatkan ukuran $30 \mathrm{~mm}$ dan $5 \mathrm{~mm}$. Untuk crust yang berukuran di atas $30 \mathrm{~mm}$ dimasukkan ke S402 sedangkan untuk crust yang berukuran di bawah $5 \mathrm{~mm}$ dimasukkan ke S-401 dan dihaluskan dengan HM-401 B.

6. Return crust kemudian masuk ke BC-404 dan masuk ke S-503.

7. Setelah crust dibersihkan maka akan dilakukan pemecahan butt.

8. Butt dipecah hingga lepas dari rod nya dipress di PR-401 dan PR-402.

9. Pemecahan butt akan jatuh ke BC-405 dan dialirkan ke CR-402 untuk dilakukan pemecahan terhadap butt

10. Kemudian dilanjutkan ke BE-402 dan diayak di SR-402 sehingga dihasilkan ukuran 150 $\mathrm{mm}$ dan $80 \mathrm{~mm}$.

11. Butt yang berukuran di atas $80 \mathrm{~mm}$ di recycle ke CR-402 untuk dipecah lagi sedangkan butt yang berukuran di bawah 80 mm akan dibawa ke BC-406 untuk memisahkan logam-logam yang terdapat di dalam butt melalui MS-402.

12. Kemudian Butt yang dihasilkan dialirkan melalui BC-407 untuk diisi ke S-403.

\section{Prosedur Press System}

1. Butt assembly yang telah dipisahkan dari crust masuk ke SH-401 untuk membersihkan crust yang masih lengket di butt.

2. Selanjutnya rakitan butt dibawa ke bagian IS-401 untuk pemeriksaan kondisi butt.

3. Di IS-401 butt dengan ketebalan kurang dari $350 \mathrm{~mm}$ dikirim ke pemecahan butt PR-401 sedangkan butt yang ketebalan lebih dari 350 mm dikirim ke PR-402.

4. Setelah butt lepas dari tangkai kemudian tangkai dikirim ke PR-403 untuk melepaskan recycle cast iron (besi tuang) dari stub sebelah rand dan PR-404 pada stub sebelah blade.

5. Recycle cast iron (besi tuang) akan dibersihkan ke SH-403 sebelum digunakan di IF.

6. Rod kemudian dikirim ke IS-402 untuk menentukan tangkai yang bagus dan tangkai yang reject.

7. Rod yang reject dikirim ke rod Repair Shop.

8. Tangkai yang masih dapat digunakan dikirim ke pembersih SH-402 untuk dibersihkan dengan shot particle.

9. Stub yang sudah bersih dicelupkan dengan grafit coating.

10. Stub yang sudah dicelupkan selanjutnya dilakukan pemanasan awal preheater.

11. Kemudian tangkai dikeringkan memakai DR401 sebelum dikirim ke casting.

12. Setelah dikeringkan tangkai dikirim ke casting untuk dilakukan proses penangkaian.

\section{Prosedur Pembuatan Cast Iron}

1. Ditimbang bahan material yang akan digunakan untuk pembuatan bahan cast iron.

2. Setelah ditimbang bahan-bahan tersebut kemudian dimasukkan ke dalam tungku induksi (induction furnace).

3. Setelah bahan-bahan material tersebut dimasukkan ke dalam tungku, bahan baku tersebut diaduk. 
4. Setelah bahan material diaduk tungku ditutup dan dipanaskan dengan suhu $1360^{\circ} \mathrm{C}$ selama 20 menit.

5. Setelah dipanaskan selama 20 menit maka tungku dibuka dan cast iron siap untuk dituangkan ke dalam leadle.

\section{Prosedur Penerimaan dan Penangkaian} Blok Anoda Panggang (Baked Block Anoda)

1. Digudang penyimpanan block anoda panggang dinaikkan ke atas $\mathrm{CM}-22$ menggunakan STC-1.

2. Kemudian diangkat ke pabrik penangkaian yang dilewatkan melalui TL-401 dan diteruskan melalui CM-402.

3. Setelah sampai di pabrik penangkaian lubang-lubang blok anoda dipanaskan di pengeringan DR-402.

4. Setelah dilakukan pengeringan maka blok anoda panggang akan dibawa ke bagian casting untuk dilakukan proses penangkaian. Setelah blok anoda panggang sampai di casting, tangkai anoda dimasukkan ke dalam lubang blok anoda panggang dan dituangkan cast iron panas ke dalam lubang blok anoda panggang.

\section{Perhitungan}

Nilai Carbon Equivalen (CE) adalah parameter yang menyatakan seberapa banyak carbon yang terkandung dalam cast iron untuk mengetahui ketahanan timbel pada saat proses penangkaian tersebut.

Rumus untuk mencari $\mathrm{CE}: \mathrm{CE}=\mathrm{C}+1 / 3(\mathrm{Si}+\mathrm{P})$ Dimana : $\mathrm{CE}=$ Carbon Equivalen

$$
\begin{aligned}
\mathrm{C} & =\text { Karbon } \\
\mathrm{Si} & =\text { Silikon } \\
\mathrm{P} & =\text { Posfor } \\
\mathrm{Mn} & =\text { Mangan } \\
\text { Gr Scrap } & =\text { Serbuk Besi }
\end{aligned}
$$

Tabel 1 Data Perbandingan bahan baku material cast iron

\begin{tabular}{clcc}
\hline No & Jenis Material & $\begin{array}{c}\text { Berat } \\
\text { Material I } \\
\text { (kg/charge) }\end{array}$ & $\begin{array}{c}\text { Berat } \\
\text { Material II } \\
\text { (kg/charge) }\end{array}$ \\
\hline 1. & Recycle cast iron & 400 & 500 \\
2. & Pig Iron & 18,3 & 22,9 \\
3. & Gr Scrap & 6,7 & 8,3 \\
4. & Silikon (Si) & 7,2 & 9,0 \\
5. & Mangan (Mn) & 1,5 & 1,8 \\
6. & Posfor (P) & 0,0 & 0,0 \\
7. & Karbon (C) & 1,6 & 2,0 \\
\hline
\end{tabular}

Sumber: PT Indonesia Asahan Aluminium
Untuk bahan material I

$$
\begin{aligned}
\mathrm{CE} & =\mathrm{C}+1 / 3(\mathrm{Si}+\mathrm{P}) \\
& =1,6+0,3(7,2+0,0) \\
& =1,6+0,3(7,2) \\
& =1,6+2,16 \\
& =3,76
\end{aligned}
$$

Untuk bahan material II

$$
\begin{aligned}
\mathrm{CE} & =\mathrm{C}+1 / 3(\mathrm{Si}+\mathrm{P}) \\
& =2,0+0,3(9,0+0,0) \\
& =2,0+0,3(9,0) \\
& =2,0+2,7 \\
& =4,7
\end{aligned}
$$

Tabel 2 Data hasil perhitungan nilai Carbon Equivalen

\begin{tabular}{llllll}
\hline No & Jenis & \multicolumn{4}{c}{ Karbon Silikon Posfor $\begin{array}{c}\text { Carbon } \\
\text { Equi- } \\
\text { valent } \\
\text { (CE) }\end{array}$} \\
\hline 1 & Bahan material I & 1,6 & 7,2 & 0,0 & 3,76 \\
2 & Bahan material II & 2.0 & 9,0 & 0,0 & 4,7 \\
\hline
\end{tabular}

\section{HASIL DAN PEMBAHASAN}

\section{Isolasi Bakteri Endofit dari Tanaman Jagung} dan Uji Hipersensitif

Salah satu faktor yang mempengaruhi kualitas dari cast iron (besi tuang) yaitu nilai Carbon Equivalen (CE). Kuat atau tidaknya cast iron tersebut tergantung dari besar kecilnya nilai Carbon Equivalen (CE) yang diperoleh di dalam cast iron tersebut.

Apabila Carbon Equivalen (CE) pada cast iron tersebut kurang dari 4,7 - 4,9 maka cast iron tersebut akan mudah retak dan terlepas dari rod (tangkai anoda). Dan apabila nilai Carbon Equivalen (CE) yang terdapat di dalam cast iron tersebut lebih dari 4,7 - 4,9 maka cast iron (besi tuang) tersebut akan sangat sulit untuk dilepaskan dari rod (tangkai anoda) karena nilai CE nya sudah mendekati baja. Dengan begitu maka pabrik akan mengalami kerugian dalam biaya produksi dan proses elektrolisa di dalam produksi tidak akan berjalan dengan baik.

Setiap material yang ditambahkan mempunyai fungsi antara lain:

a. Karbon, untuk pembentukan struktur grafit dan $\mathrm{Fe}_{3} \mathrm{C}$ (sementit) sehingga cast iron menjadi lebih keras.

b. Phosfor, dapat menurunkan titik lebur cast iron dan membentuk fluiditas cast iron.

c. Ferro Silikon, sebagai penguat karbon dalam pembentukan struktur grafit dan fluiditas cast iron. 
d. Mangan, sebagai pereaksi dengan Sulfur membentuk mangan sulfida yang berfungsi sebagai 'desulfuring agent'.

Kelebihan sulfur dapat mengakibatkan temperatur didih meningkat, mengganggu fluiditas dan dapat mencegah pembentukan Kristal grafit.

Dari hasil perhitungan di atas, dihasilkan nilai Carbon Equivalen (CE) cast iron (besi tuang) yaitu 3,76 dan 4,7. Pada bahan material cast iron II ditemukan nilai Carbon Equivalen nya sesuai dengan standart mutu dan karakteristik yang diinginkan yaitu 4,7 - 4,9.

\section{KESIMPULAN}

1. Nilai Carbon Equivalen(CE) yang dihasilkan dari hasil pengamatan yaitu 3,76 dan 4,7

2. Faktor-faktor yang mempengaruhi nilai Carbon Equivalen (CE) cast iron adalah

a. Silikon (Si) sebagai penguat karbon dalam pembentukan struktur grafit dan fluiditas cast iron

b. Mangan $(\mathrm{Mn})$ sebagai pereaksi dengan sulfur sehingga membentuk mangan sulfide yang berfungsi sebagai 'desulfing agent'. Kelebihan sulfur dapat mengakibatkan temperatur didih meningkat, mengganggu fluiditas dan dapat mencegah pembentukan Kristal Grafit.

c. Phospor (P) menurunkan titik lebur cast iron dan membentuk fluiditas cast iron

d. Carbon (C) untuk pembentukan struktur grafit dan $\mathrm{Fe}_{3} \mathrm{C}$ (sementit) sehingga cast iron jadi lebih keras.

\section{SARAN}

1. Untuk mendapatkan cast iron yang baik dan sesuai dengan standart yang diinginkan maka harus memperhatikan faktor-faktor yang mempengaruhi mutu dari cast iron tersebut.

2. Untuk mendapatkan kualitas aluminium yang baik dan sesuai yang diinginkan maka kita harus meningkatkan kualitas anoda yang dihasilkan.

3. Untuk mendapatkan kualitas anoda yang baik maka kita juga harus memperhatikan kebersihan dari butt atau puntung anoda yang akan digunakan kembali.

4. Diharapkan dilakukan penelitian lebih lanjut tentang peningkatan kualitas anoda dengan memperhatikan faktor-faktor lain yang mempengaruhinya.

\section{DAFTAR PUSTAKA}

Bagotsky, V.S. 2006. Fundamental of electrochemistry. New Jersey: John Wiley and Sons Inc.

Donet, J.B. 1970. Carbon Black, Physics, Chemistry, and Reinforcemenr. New York: Marcel Dekker.

Grjotheim, K. and B.L. Welc. 1988. Aluminium Smelter Tecnology. Second edition. Dussldorf: Aluminium Verlag

Iwasita, T. 2004. Fuel cell-fundamental, technology and application. Vol.2: Electrocatalysis, New York : John Wiley \& Sons.

Jan, P.L. 1979. Principal of Foundry Technology. New Delhi: Tata Mc Graw Hill Publishing Company

PT INALUM. 1998. Produksi Aluminium Dengan Proses Elektrolisa, Asahan: PT INALUM

PT INALUM. 2003. Manual Operation Green Plant, Baking Plant and Rodding Plant. Seksi Karbon. Asahan: PT INALUM

Riyanto. 2013. Elektrokimia dan Aplikasinya. Edisi Pertama. Yogyakarta: Graha Ilmu.

Ross, S.D., Finkelstein, M. \& Rudd, E.F. 1975. Anodic oxidation. New York: Academic Press.

Sukandarumidi, 2008. Geologi Mineral Logam. Yogyakarta: Gajah Mada University Press.

Sumanto, M.A. 1994. Pengetahuan Bahan Untuk Mesin dan Listrik. Edisi Pertama. Yogyakarta: Andi Offset.

Utomo, Tjipto. 1984. Teori Dasar Fenomena Transpor, Bina Cipta.

Xu, Y., Page, T., Shamona, L., Noding, S., Modrow, H., Hormes, J., Satyanayarana, N. \& Rambabu, B. 2004. A study of electrochemical and structural properties of carbon supported electrodes, new catalysts and ion conducting membranes. Proceeding of the $38^{\text {th }}$ Intersociety Energy Conversion Engineering Conference, Germany: 1254-1259. 